\title{
Enhanced production of xylanase enzyme by Fusariummoniliforme using submerged fermentation
}

\section{Th. H. Shaltout ${ }^{2}$, Z. H. Kheiralla ${ }^{1}$, N. Sh. El-Gendy ${ }^{2}$, H. A. Ahmed ${ }^{1}$, and M. M. D. Hussein ${ }^{3}$}

${ }^{1}$ Botany Department,Faculty of Women for Arts, Science and Education, Ai Shams University.

${ }^{2}$ Petroleum Biotechnology lab, Department of Processes Design \& Development,Egyptian Petroleum Research Institute, Nasr City, Cairo, Egypt.

${ }^{3}$ Chemistry of Natural and Microbial Products Department, National Research Center, Dokki, Giza, Egypt.

\begin{abstract}
:
Hemicellulose degrading enzymes play an important role in bioconversion of agro and agro-industrial wastes. In this study, production of hemicellulase by six fungal isolates was determined under submerged culture using corn cobs xylan as a carbon source and enzyme inducer at different incubation periods. The results indicated that Alternariatenuisshowed the lowest enzyme productivity $(156.95 \pm 2.07 \mathrm{U} / \mathrm{l})$ while the highest enzyme production $(2,594.44 \pm 62.25 \mathrm{U} / \mathrm{l})$ was found by Fusariummoniliforme. One-factor-at-atime (OFAT) revealed maximum enzyme productivity of 10,950.11 \pm 98.45 $\mathrm{U} / \mathrm{l}$ at; corn cobs xylan $(6 \mathrm{~g} / \mathrm{l})$, yeast extract $(4 \mathrm{~g} / \mathrm{l})$, inorganic salts $\left(\mathrm{MgSO}_{4}\right.$, $\mathrm{KH}_{2} \mathrm{PO}_{4}, \mathrm{CaCl}_{2}, \mathrm{FeSO}_{4}$, and $\mathrm{MnSO}_{4}$ ), initial $\mathrm{pH}$ (5), initial inoculum size (4\%), $150 \mathrm{rpm}$ and temperature $\left(30^{\circ} \mathrm{C}\right)$.
\end{abstract}

Key words:Xylanase;Fusariummoniliforme;submerged fermentation;corn cob xylan

*Corresponding author: Micro_1a@yahoo.com 


\section{Introduction:}

Enzymes are used to produce a wide range of biotechnologicalproducts utilized by the food, chemical, and allied industries andhave been already recognized as valuable catalysts for productionof fine chemicals and pharmaceuticals and several organic transformations[1].Hemicellulose is a branched hetero-polymer consisting of pentose (d-xylose and d-arabinose) and hexose (d-mannose, d-glucoseand d-galactose) sugars where xylose is most abundant. Hemicellulose is the one of the most abundant second renewable biomassin nature after cellulose, which accounts for $25-35 \%$ of lignocellulosic biomass [2]. The most abundant hemicellulose in natureis xylan which contains mainly -d-xylopyranosyl residues linkedby $\beta-1,4-$ glycosidic bonds $[3,4]$.

In plants, an overlying layer ofxylan and cellulose forms through hydrogen bonding which is further covalently linked with lignin leads to formation of an outsidesheath for the protection of the plant. Xylan accounts for 30-35\% of total dry weight, however, the exact amount of the xylandifferefrom plants to plants which display a large variation in composition during extraction from different sources $[4,5]$.

Hemicelluloses degradation needs the hemicellulytic enzymes. These enzymes have wide range of applications such as utilization of lignocellulosic substances to cellulosic bioethanol, clarification of juice and animal feed, in paper industry, etc. [2]. These enzymes are produced by a large number of microorganisms such as bacteria, actinomyces, and fungi, but fungi have a great interest because they excrete their enzymes extracellularly[6].

Xylan, with its $\beta-1$, 4-linked polyxylose backbone branched with other pentoses, hexoses and uronic acids, is the main component of hemicellulose. [7,8]. Among the xylanolytic enzymes, endo-1, 4- $\beta$-xylanases (play important roles during hydrolysis of xylan, as they can cleave $\beta-1$, 4-linked xylose backbone of xylan[2].Filamentous fungi are particularlyremarkable producers of xylanases from an industrial point of view, owing to the fact that they secrete xylan-degrading enzymes into the medium, thus avoiding cell disruption. Furthermore, the xylanase levels obtained from fungal cultures are typically much higher than those obtained from yeast or bacteria. In addition, fungi typically produce several auxiliary enzymes that are necessary 
for debranching of the substituted xylans[9].Mostly the production of xylanases has been studied in submerged liquid culture but there are few reports concerning the xylanase production in solid state fermentation using lignocellulosic wastes. Submerged fermentation process is mostly preferable because of more nutrients availability, sufficient oxygen supply and less timerequired for the fermentation than other fermentation techniques.

The present work aims to optimizexylanaseproductivity byF.moniliforme using submerged fermentation.

\section{Materials and methods}

\subsection{Fungal strains:}

The hemicellulolytic activities of six fungal isolates were investigated throughtout the present work.Alternariatenuis, F. moiliforme, $F$. oxysporum were isolated from old deteriorated valuable manuscript(Al Sultan Malak, library No.1405)present in the Stores of General Egyptian Book Organization(G.E.B.O).Cairo, Egypt .Mucormucedo ,RhizoctoniaSolani, Rhizopusoryzawere isolated from rhizosphere of local tomato plant . Isolation and identification of these fungi were achieved by Dr.A.F.Sahab, Plant protection Lab, Plant Pathology department, National Research Centre. The fungal strains were grown on potato dextrose agar medium (PDA).Slants were incubated at $30^{\circ} \mathrm{C}$ for 7 days and stored in a refrigerator at $\mathrm{PC}$.

\subsection{Inoculum preparation:}

This was done by adding $10 \mathrm{ml}$ normal saline $(0.9 \mathrm{gNaCl} / 100 \mathrm{ml})$ to each 7 days old cultureand scratched with sterile needle.This spore suspension was used as inoculums. The tube was shacked to make homogenous.

\subsection{Fermentation technique:}

Cultivation was carried out in $250 \mathrm{ml}$ Erlenmeyer flasks, each containing $25 \mathrm{ml}$ of the fermentation medium[10]. , it contained $\mathrm{KH}_{2} \mathrm{PO}_{4}(1.5 \mathrm{~g} / \mathrm{l})$ $\mathrm{MgSO}_{4} .7 \mathrm{H}_{2} \mathrm{O}(1.0 \mathrm{~g} / \mathrm{l}), \mathrm{CaCl}_{2}(0.2 \mathrm{~g} / \mathrm{l}), \mathrm{FeSO}_{4} .7 \mathrm{H}_{2} \mathrm{O}(0.4 \mathrm{~g} / \mathrm{l}), \quad \mathrm{MnSO} 4.5 \mathrm{H} 2 \mathrm{O}$ $(0.3 \mathrm{~g} / \mathrm{l})$, yeastextract $(2 \mathrm{~g} / \mathrm{l})$. The $\mathrm{pH}$ was adjusted by adding $1 \mathrm{~N} \mathrm{NaOH}$. Carbon source was corn cobs xylan and sterilized for $15 \mathrm{~min}$ at $121^{\circ} \mathrm{C} \quad(1.5$ atm). The flasks were then inoculated with $1 \mathrm{ml}$ of fungal conidial suspension 
under aseptic condition and incubated at $30^{\circ} \mathrm{C}$ on a rotary shaker at $150 \mathrm{rpm}$ for several days. After incubation for different periods the culture broth from each flask was centrifuged in cooling centrifuge at 4000rpm for 10 minutes. The clear culture filtrate was taken in which the protein content and enzyme assays were determined. All experiments were run parallel in duplicate.

\subsection{EstimationEnzymeactivity:}

The diluted culture filtrate or enzyme solution $(0.2 \mathrm{ml})$ was added to $0.8 \mathrm{ml}$ of hemicellulosic suspension $(2.5 \%)$ in $0.05 \mathrm{M}$ citrate buffer ( $\mathrm{PH} 4.8)$. The reaction mixture was then incubated at $50{ }^{\circ} \mathrm{C}$ for $30 \mathrm{~min}$.The released reducing sugars were determined as xylose by Nelson's reagent according to [11]. . Enzyme activities were determined in culture filtrate by measuring the released sugars from substrates. One unit of enzyme activities was defined as the amount of enzymes required to release $1 \mu$ mol of xylose per min under the assay conditions.

\subsection{Determination of soluble protein:}

Soluble protein content of the studied sample was determined by the method of [12].

\subsection{Optimization of cultural conditions for maximum production of xylanaseby selected fungal isolates:}

Various nutritional conditions like different concentration of carbon source (2-10 g/l), different nitrogen sources (yeast extract ,backer's yeast, soybean milk, corn steep liquor, urea, $\left.\mathrm{NaNO}_{3},(\mathrm{NH} 4)_{2} \mathrm{SO}_{4}, \mathrm{NH} 4 \mathrm{Cl}\right)$, different concentration of yeast extract (1- $6 \mathrm{~g} / \mathrm{l})$, different inorganic salts( $\mathrm{MgSO}_{4}, \mathrm{KH}_{2} \mathrm{PO}_{4}, \mathrm{CaCl}_{2}, \mathrm{FeSO}_{4}, \mathrm{MnSO}_{4}$ )and some culture condition Such as intial pH (4.5-7 ),Inoculum size (2-10), different r.p.m. (0,150,180), different temperature $(25,30,37)$ and some additives with different concentrations such as(Tween80(1-3ml/l), wheat bran(1-5g/l) and glucose(1-5g/l)).

\subsection{Statistical analysis:}

The differences in enzymes activities variables among the treatment effects were tested using F-test. In addition, After testing the data for normality, one way analysis of variance (ANOVA) was used to assess the significance of variations of enzymes activities among the 
different treatment effects by using Duncan's multiple range tests at $\mathrm{P}<$ 0.05 according to SPSS software [13].

\section{Results}

\subsection{Screening of some fungal isolates for theirxylanaseactivity:}

Table, 1 showed the results of the wide range of differences were observed in the hemicellulytic activities of the investigated fungal isolates. The highest hemicellulase activities $2594.44 \pm 62.25 \mathrm{U} / 1$ recorded in the culture filtrate of $F$. moniliformeisolated from old deteriorated valuable manuscript.

Noteworthy, is that most of the studied fungal isolates showed their higher hemicellulytic activities (Table 1) after 7 days (other than 14 days) of incubation.

\subsection{Optimization of cultural conditions for maximum production of xylanase by selected fungal isolates.}

Based on the results of Table (1), the highest values were showed by each of F.moniliforme. Consequently, this isolate was selected to undertake the next parts of the present work.

Table (1): Table (1) xylanase activity of the tested fungi.

\begin{tabular}{|c|c|c|c|c|c|}
\hline Fungal strain & $\begin{array}{l}\text { incubation } \\
\text { Period } \\
\text { (day) }\end{array}$ & $\begin{array}{l}\text { Final } \\
\text { PH }\end{array}$ & $\begin{array}{l}\text { Dry weight of } \\
\text { cells and } \\
\text { residual } \\
\text { hemicelluloses } \\
(\mathrm{g} / \mathrm{l})\end{array}$ & $\begin{array}{l}\text { Protein } \\
\text { Content } \\
\text { Of } \\
\text { c.f. } \\
(\mu \mathrm{g} / \mathrm{l})\end{array}$ & $\begin{array}{l}\text { Hemicellulase } \\
\text { activitiy } \\
\text { (U/I ) }\end{array}$ \\
\hline \multirow[t]{2}{*}{ Rhizopusoryzae } & 7 & 7.5 & 2.56 & 38.02 & $296.10 \pm 2.51 \mathrm{~d}$ \\
\hline & 14 & 7.5 & 1.78 & 66.54 & $555.56 \pm 1.53 \mathrm{c}$ \\
\hline \multirow{2}{*}{$\begin{array}{l}\text { Rhizoctonia } \\
\text { Solani }\end{array}$} & 7 & 7 & 2.56 & 67.93 & $222.23 \pm 2.51 \mathrm{e}$ \\
\hline & 14 & 7.5 & 2.37 & 118.88 & $60.00 \pm 1.53 \mathrm{~g}$ \\
\hline \multirow{2}{*}{$\begin{array}{l}\text { Fusarium } \\
\text { moiliforme }\end{array}$} & 7 & 7 & 3.44 & 90.10 & $\begin{array}{l}2594.44 \pm 62.25 \\
\text { a }\end{array}$ \\
\hline & 14 & 7 & 2.82 & 56.55 & $\begin{array}{l}1766.67 \pm 32.64 \\
b\end{array}$ \\
\hline \multirow{2}{*}{ Alternariatenuis } & 7 & 6.5 & 2.192 & 106.60 & $174.44 \pm 3.11 \mathrm{f}$ \\
\hline & 14 & 7 & 2.22 & 83.52 & $156.95 \pm 2.07 \mathrm{f}$ \\
\hline \multirow{2}{*}{ Fusariumoxysporum } & 7 & 7 & 2.72 & 131.95 & $187.26 \pm 0.38 \mathrm{f}$ \\
\hline & 14 & 7 & 2.82 & 56.55 & $223.65 \pm 0.34$ ef \\
\hline \multirow{2}{*}{ Mucormucedo } & 7 & 7 & 2.30 & 67.61 & $2268.93 \pm 20.07 \mathrm{a}$ \\
\hline & 14 & 7 & 1.55 & 134.85 & $1032.58 \pm 37.67 \mathrm{~b}$ \\
\hline
\end{tabular}


The mean values of the enzyme activities \pm SD are presented. The different letters show significant difference $(P<0.05)$.

\subsubsection{Effect of differentcarbon sources concentrations on hemicellulase production:}

The results of Figure 1 revealed that the highest hemicellulase values 5618.5U/l were showed by F.moniliforme by using corn cobs xylan $6 \mathrm{~g} / \mathrm{l}$. The statistical results showed thatthe concentrations 4 and $10 \mathrm{~g} / \mathrm{l}$ were nonsignificant effect on xylanase activity by F.moniliforme. Total soluble protein was estimated with enzyme activity. According to the data represented in fig (1), enzyme activity affected on the total protein produced, parallel.

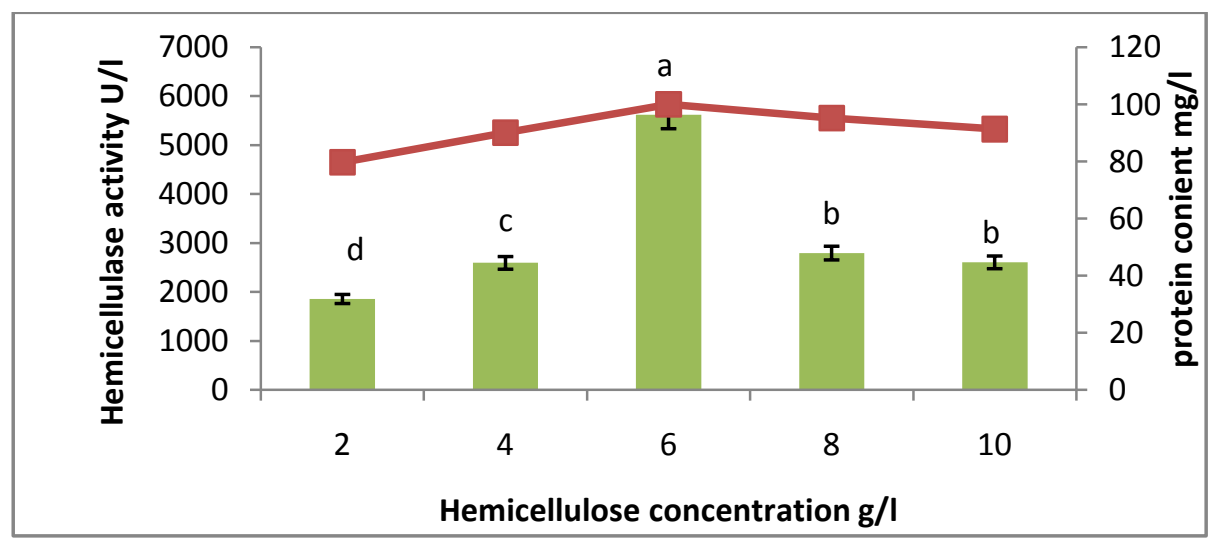

Fig. 1: Effect of different concentration of carbon source on hemicellulase of Fusariummoniliforme. The mean values of the enzyme activities \pm SD are presented. The different letters show significant difference $(P<\mathbf{0 . 0 5})$. 


\subsubsection{Effect of different nitrogen:}

The result of fig. 2 showed that the yeast extract (control $\mathrm{N}$ source) was selected as the most suitable $\mathrm{N}$ source to be used in the next parts of the present work. The statistical results showed that corn steep liquor and $\mathrm{NaNo}_{3}$ had non-significant effect xylanase activity by Fusariummonilifrome. The nature of nitrogen source has considerable effect on enzyme activity and total protein content. By using organic nitrogen sources, there was semi stability with fewer differences in enzymes activities. There were higher differences in total protein with using inorganic nitrogen ranged from (63.21 $\mathrm{mg} / \mathrm{l}$ by using ammoniumchloride) to $(81.60 \mathrm{mg} / \mathrm{l}$ by using sodium nitrate).

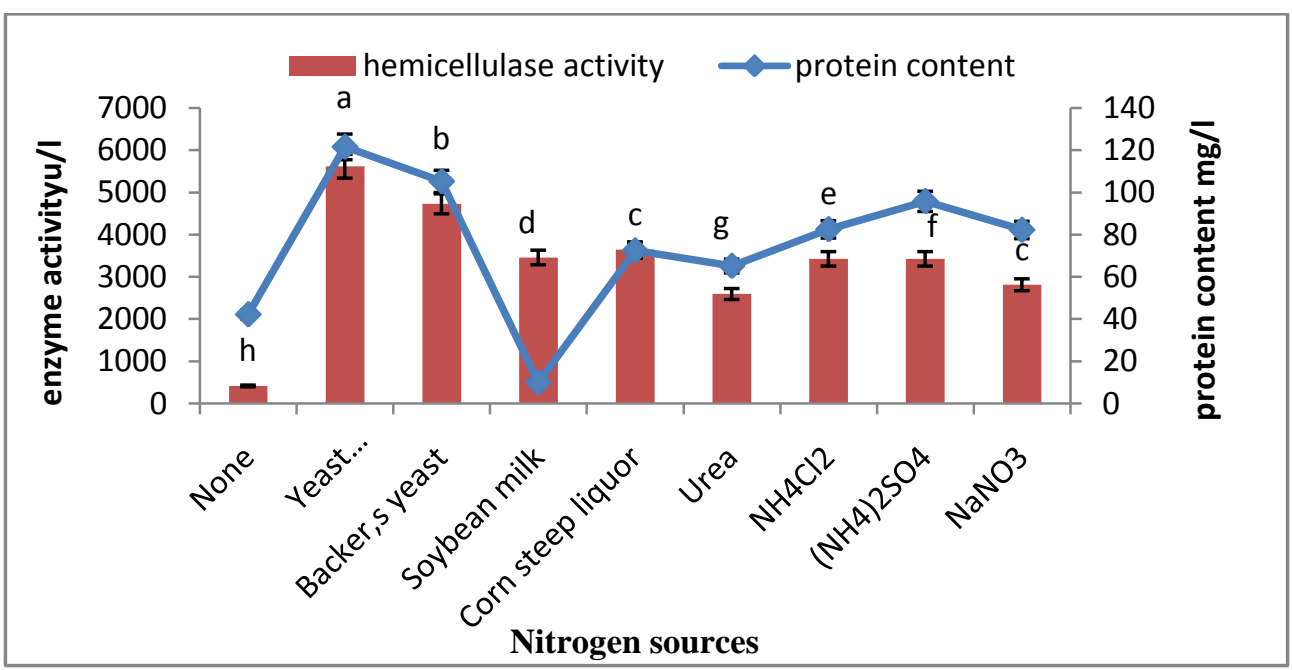

Fig. 2: Effect of different nitrogen sources on hemicellulase activity of Fusariummoniliforme. The mean values of the enzyme activities \pm SD are presented. The different letters show significant difference $(P<0.05)$. 


\subsubsection{Effect of different yeast extract concentrations:}

The results of Fig.3 indicated that on using $4 \mathrm{~g} / \mathrm{L}$ yeast extract, F.moniliformeexhibited their highest hemicellulase activity 8074.04U/1, respectively. Thus, yeast extract (at $4 \mathrm{~g} / \mathrm{l}$ ) was chosen to be used (as $\mathrm{N}$ source) in the next experiments during this study.

The statistical results showed that allThe concentrations 1 and2g/l yeast extract were non-significant effect on xylanase activity by F.moniliforme. Soluble protein increased with increasing of yeast extract concentration. The total protein content affected parallel with enzyme activity.

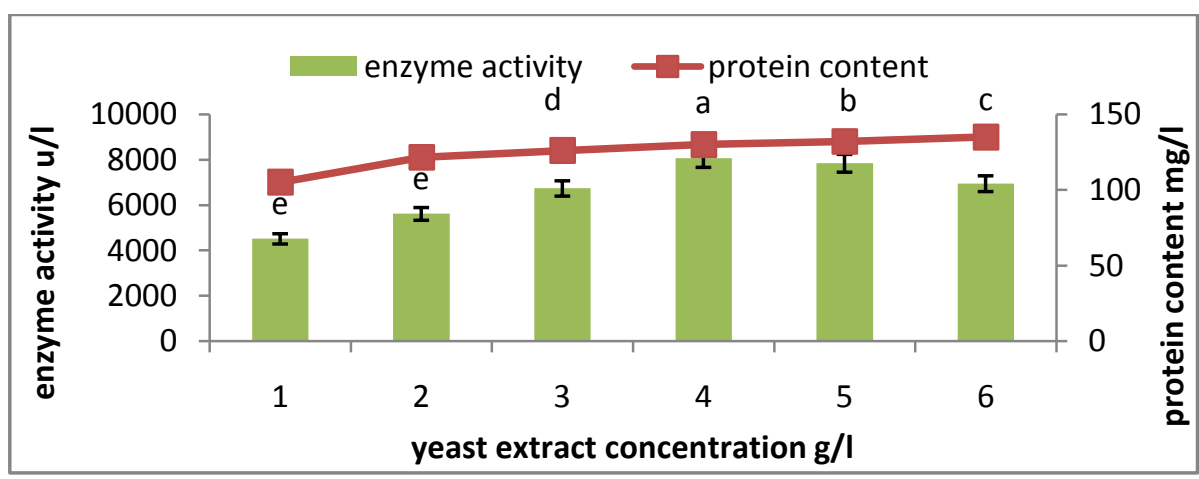

Fig.3: Effect of different yeast extract concentrations on hemicellulase activity of Fusariummoniliforme. The mean values of the enzyme activities \pm SD are presented. The different letters show significant difference $(\mathrm{P}<\mathbf{0 . 0 5})$. 


\subsubsection{Effect of inorganic salts:}

The results of Fig.4 revealed that F.moniliforme was needed for all of the tested inorganic salts to exhibit its own higher activity. The statistical results showed that all Elimination of $\mathrm{MgSo}_{4}$ and $\mathrm{CaCl}_{2}$ had non-significant effect on xylanase activity by F.moniliforme. The total protein content affected parallel with enzyme activity.

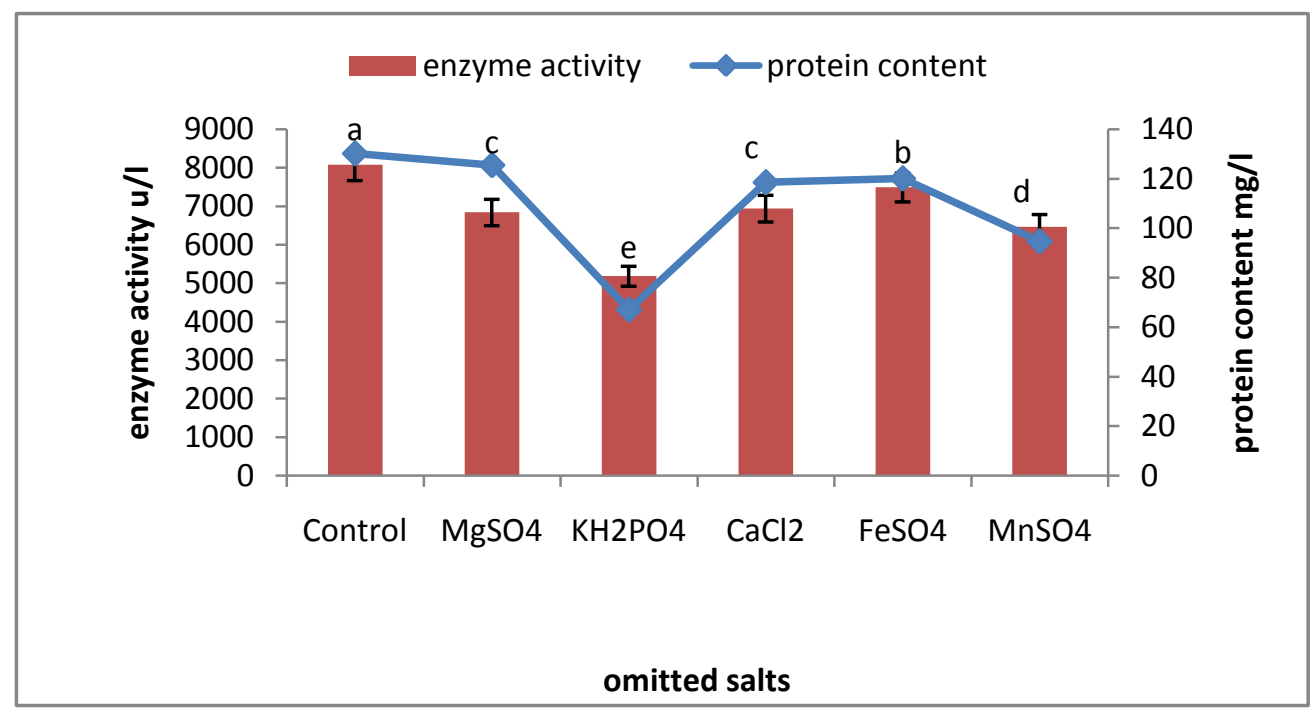

Fig.4: Effect of inorganic salts used in studied media on hemicellulase activity of Fusariummoniliforme. The mean values of the enzyme activities \pm SD are presented. The different letters show significant difference $(\mathrm{P}<\mathbf{0 . 0 5})$. 


\subsubsection{Effect of initial pH-values:}

The results of Fig. 5indicated that F.moniliformeled to production of the highest hemicellulase activities were 10950.11U/l. Based on these data the initial $\mathrm{pH}$-value was adjusted at $\mathrm{pH} 5$ for growing the selected fungal isolates in the next experiments.

The statistical results showed that $\mathrm{pH}$ (4.5and 6) had non-significant effect on xylanase activity byand $F$. moniliforme .The total protein content affected parallel with enzyme activity.

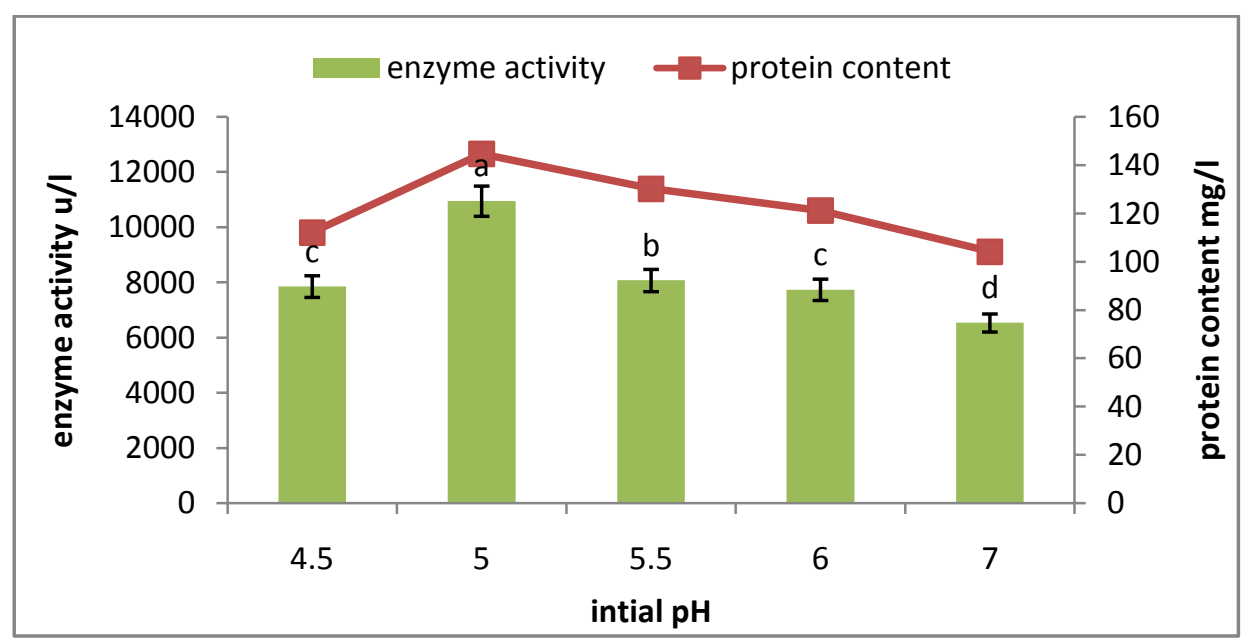

Fig.5: Effect of initial pH on hemicellulase activity of Fusariummoniliforme. The mean values of the enzyme activities \pm SD are presented. The different letters show significant difference $(P<0.05)$. 


\subsubsection{Effect of inoculums size:}

The results of Fig.6 revealed that the control inoculum size (4\%) was found optimal for production of highest hemicellulase activities10950.11U/1 of $F$. moniliforme. Thus, the inoculum size $4 \%$ was applied to grow the selected fungal isolates in the next experiments.

According to statistical results.inoculum sizes 2 and $10 \%$ had non-significant effect on xylanase activity on xylanase activity by $F$. moniliforme. The total protein content affected parallel with enzyme activity.

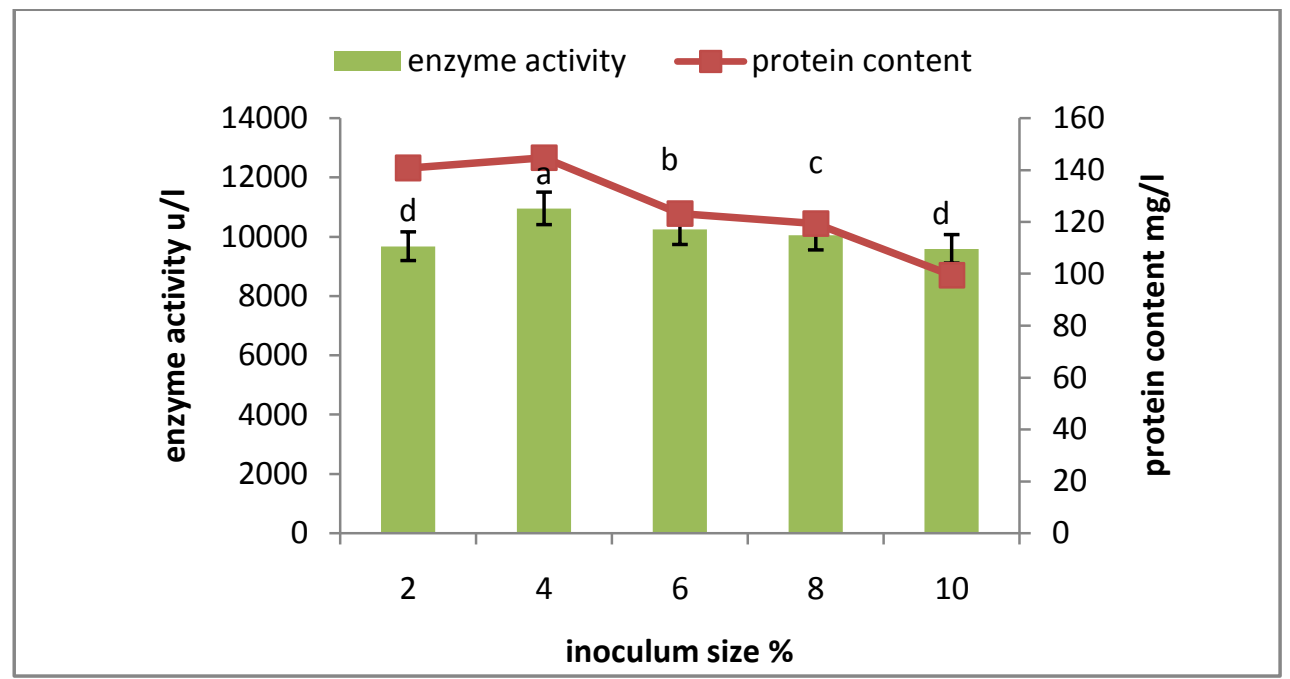

Fig. 6: Effect of different inoculum size on hemicellulases activity by Fusariummoniliforme. The mean values of the enzyme activities $\pm \mathrm{SD}$ are presented. The different letters show significant difference $(P<0.05)$. 


\subsubsection{Effect of aeration rate:}

The data of Fig. 6 indicated that shaking at 150 r.p.m. (control condition) afforded the optimal aeration rate for secretion of hemicellulase enzymes by the chosen fungal isolates. According to statistical results, all trials had significant effect on enzymes activities. The total protein content affected parallel with enzyme activity.

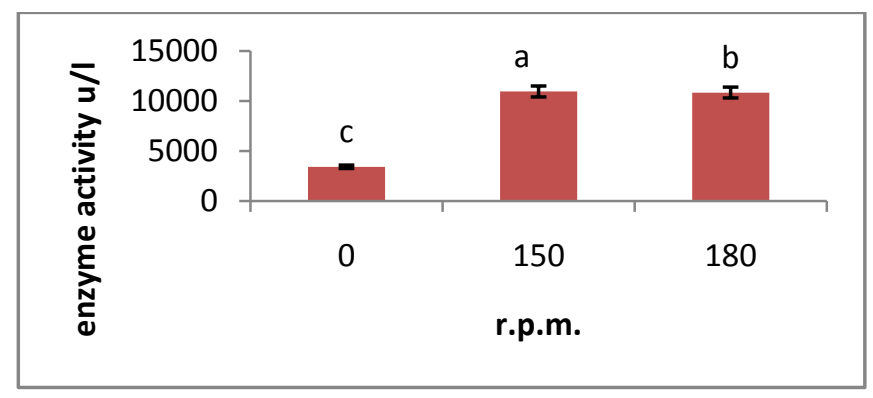

Fig. 7: Effect of different (r. p.m) on hemicellulases activity by Fusariummoniliforme. The mean values of the enzyme activities $\pm \mathrm{SD}$ are presented. The different letters show significant difference $(P<0.05)$.

\subsubsection{Effect of Incubation Temperature:}

The data recorded in Fig. 8 showed that the control temperature, i.e., $30^{\circ} \mathrm{C}$, was found the optimal one .Hence, the incubation of selected fungal isolates was carried out (in the next experiments) at $30^{\circ} \mathrm{C}$.According to statistical results, all trials had significant effect on enzymes activities. The total protein content affected parallel with enzyme activity

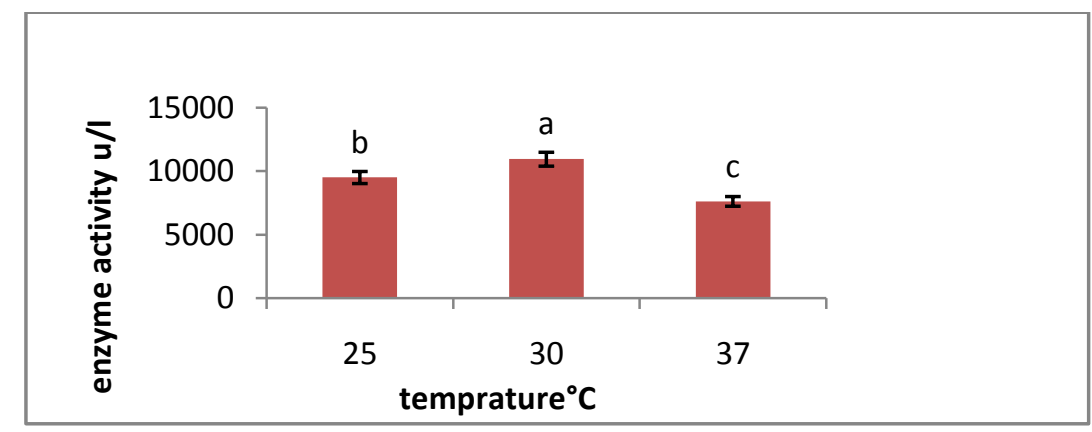

Fig. 8: Effect of different temperature on hemicellulase activitybyFusariummoniliforme. The mean values of the enzyme activities $\pm \mathrm{SD}$ are presented.

The different letters show significant difference $(P<0.05)$. 


\subsubsection{Effect some additives:}

The data of Fig.9 revealed that the supplementation with any of the aforementioned additives did not enhance the hemicellulase activities of F.moniliforme. Thus, no additives were used in the next experiment.

Statistical results showed that Wheat bran $(5 \mathrm{~g} / \mathrm{l})$ and glucose $(3 \mathrm{ml})$ had non-significant effect xylanase and Wheat bran $(1 \mathrm{~g} / \mathrm{l})$ and glucose $(1 \mathrm{~g} / \mathrm{l}) \mathrm{had}$ non-significant effect xylanase activity by F.moniliforme. The nature of additives affected on total protein content. Tween $80(1,2 \mathrm{ml} / \mathrm{l})$ has semi stability in protein content ,but $(3 \mathrm{ml} / 1)$ has increased the total protein with less increase in CMCase activity and less decrease in FPaseactivity.there was higher differences in protein content by using wheat bran as additives ranged from $(84.50$ to $107.52 \mathrm{mg} / \mathrm{l})$. By using glucose protein content ranged from ( 80.77 to 89.55$)$.

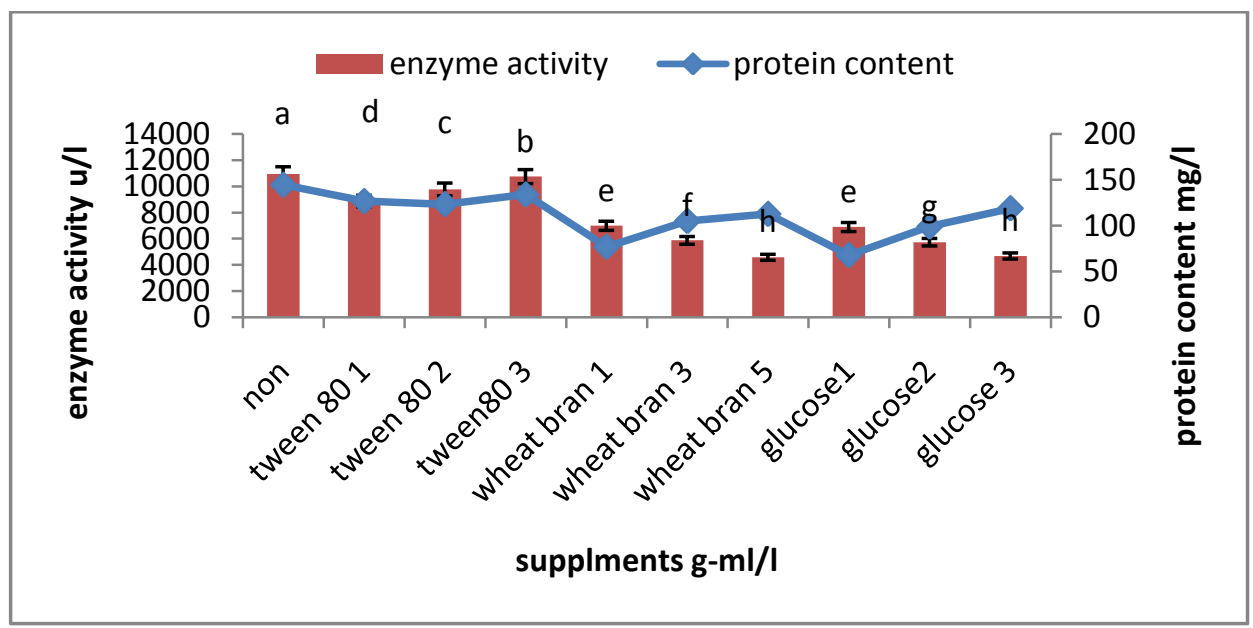

Fig.9: Effect of some supplements addition with different concentrations on hemicellulase activityby Fusariummoniliforme. The mean values of the enzyme activities \pm SD are presented. The different letters show significant difference $(\mathrm{P}<\mathbf{0 . 0 5})$.

\section{Disscusion}

Recently, xylanase has become an essential option for environmental friendly industrial biotechnological applications [14.15]. The xylanase enzyme can be produced by a number of microorganisms, however, 
filamentous fungi are considered as more potent producers of xylanases[16, 17]. Six fungal isolates were selected for the xylanase production based on their ability to hydrolyze xylan in the medium. The maximum enzyme production was observed in Fusariummoniliforme $(2594.44 \pm 62.25 \mathrm{U} / \mathrm{l})$.

The optimization of medium composition is done to maintain a balance between the various medium components in production media which is done for commercial practice. Optimization helps minimizing the amount of unutilised components at the end of fermentation. Research efforts have been paying attention mainly towards evaluating the effect of various carbon, nitrogenous nutrients, metal ion, phosphate and salt as cost-effective substrates on the yield of enzymes [18].xylanases are produced worldwide through SmF which allows better control environment during aerobic fermentation process. It has been found that $\mathrm{SmF}$ is normally preferred when the preparations require more purified enzymes [19]

The effect of carbon and nitrogen sources on secondary metabolism is trained by several factors including the type of metabolic pathway, the producing organism, the type and concentration of the sources and whether cultures are stationary or submerged. In SmF, purified xylan is frequently used in bioprocesses for xylanase production. Most microorganisms can utilize both inorganic and organic forms of nitrogen which are required to produce amino acids, nucleic acids, proteins and other cell wall components. Recently, [20] isolatedA. niger from garden soil and investigated the effect of different parameters for maximum xylanase production in shake flask. It has been observed that maximum xylanase production was found in presence of xylan as carbon source and yeast extract as nitrogen source, these resulte agreed with the result in the present work.

Fungi require a unique combination of several unusual nutrient conditions, that is, hydrogen ions, dissolved oxygen certain trace metals, or phosphate for sufficient growth or xylanase production. $\mathrm{Fe}^{2+}, \mathrm{Mg}^{2+}, \mathrm{Mn}^{2}$ have positive effect on xylanaseactiviry[21].

The cultivation $\mathrm{pH}$ exerts a major influence on the overall fermentation efficiency. This is largely because the $\mathrm{pH}$ of the medium changes in response to the metabolic activities taking place. For example, the secretion of organic acids such as citric, acetic, and lactic acids will cause the $\mathrm{pH}$ to decrease, 
while the uptake of organic acids present in some nutrient media can lead to an increase in $\mathrm{pH}$. Enzymatic activity is usually strongly influenced by $\mathrm{pH}$, because the active sites of enzymes often depend on the presence of ionic species to maintain conformations that enable efficient binding to the substrate. [22]reported that Optimum $\mathrm{pH}$ of xylanase production by fungi ranged from 4.5 to6 which agree with the result in the present work.

Highest enzyme activity appeared by inoculum size $4 \%$ and decreased by higher inoculum sizes .These results indicated that Increased level of inoculum mostlyreduced xylanase production in industrial fermentation process [23]. This may be due to the depletion ofnutrients from the fermentation medium which resulteddecline in enzyme synthesis.

The function of aeration is to maintain aerobic conditions, remove the carbon dioxide generated, and regulate the temperature and moisture level of the substrate.In aerobic SmF cultivations, the oxygen supply is often the limiting factor for growth, due to low solubility of oxygen in water. In the present work 150 r.p.m. was the optimum aeration rate.[22]

Incubation temperature is also a critical factor in the growth of fungus. Different experiments were performed on variousincubation temperatures ranging from 20 to $50{ }^{\circ} \mathrm{C}$. Results ofthe study indicated that maximum enzyme production wasnoted at $30^{\circ} \mathrm{C}$. this results agree with the result of the present work. The incubation temperature was further increased decrease in enzyme production was also observed. Due to increasing the enzyme activity, some supplements were added to the optimized medium.Unfortunately, all supplemented tested have negative effect on enzyme activity. This result disagreed with [23]

\section{Conculsion:}

The fungal strainF.moniliformeexpresses good xylanaseactivity, using the agro-industrial wastes; corn cobs xylan, as an individual carbon source and inducer(2,594.44 $\pm 62.25 \mathrm{U} / \mathrm{l})$. Upon optimization the enzyme productivity was approximately increased by four times, recording maximum enzyme productivity10,950.11 $\pm 98.45 \mathrm{U} / \mathrm{l}$, under optimum operating conditions of; corn cobs xylan $(6 \mathrm{~g} / \mathrm{l})$, yeast extract $(4 \mathrm{~g} / \mathrm{l})$, inorganic salts $\left(\mathrm{MgSO}_{4}, \mathrm{KHPO}_{4}\right.$, $\mathrm{CaCl}_{2}, \mathrm{FeSO}_{4}$, and $\mathrm{MnSO}_{4}$ ), initial $\mathrm{pH}$ (5), initial inoculum size (4\%), 150 
rpm and temperature $\left(30^{\circ} \mathrm{C}\right)$. Thus, optimization of process parameters is a prerequisite to enhance the enzyme yield and activity, which is very helpful in large-scale production.

\section{Refrences:}

AfolakeAtinuke Olanbiwoninu1, Sunday AyodeleOdunfa Production of Cellulase and Xylanase by AspergillusterreusKJ829487 Using Cassava Peels as Subtrates Advances in Microbiology, 2016, 6, 502-511.(2016).

AriefWidjaja, Akbar Tanjung, Hiroyasu Ogino, Optimized production of xylanase from fungal strains and its purification strategies. Journal of Applied Sciences in Environmental Sanitation 4(3) (2009). 219-232.

B.Bhunia, B. Basak, T. Mandal, P. Bhattacharya, A. Dey, Effect of $\mathrm{pH}$ and temperature on stability and kinetics of novel extracellular serine alkaline protease (70 kDa), Int. J. Biol. Macromol. 54 (2013)1-8.

B.C Saha., Hemicellulose bioconversion, J. Ind. Microbiol. Biotechnol. 30 (2003) 279-291

Farinas Cristiane S, Developments in solid-state fermentation for the production of biomass-degrading enzymes for the bioenergy sector. Renewable and Sustainable Energy Reviews 52(2015) 179-188.

Garcia-Kirchner O., M. Munoz-Aguilar, R. Perez-Villalva, C. HuitronVargas, Mixed submerged fermentation with two filamentous fungi for cellulolytic and xylanolytic enzyme production, Appl. Biochem. Biotechnol. 98-100: . (2002)1105-1114

Guan Guo-Qiang, Peng-Xiang Zhao, Jin Zhao,3 Mei-Juan Wang, ShuHaoHuo, Feng-JieCui,andJian-XinJiang Production and Partial Characterization of an Alkaline Xylanase from a Novel Fungus Cladosporiumoxysporum, BioMed Research International Volume 4575024, .(2016).7pageshttp://dx.doi.org/10.1155/2016/4575024

Harshvardhan K., A. Mishra, B. Jha, Purification and characterization of cellulasefrom a marine Bacillus sp. H1666: a potential agent for single 
stepsaccharification of seaweed biomass, J. Mol. Catal. B Enzy 93 5156.8524(96)0009(2013) 4-6.

HuiZhang, Qing Sang,. Production and extraction optimization of xylanase and $\beta$-mannanase by Penicilliumchrysogenum QML-2 and primary application in saccharification of corn cob, Biochemical Engineering Journal 97(2015) 101-110.

IrfanMuhammad , Muhammad Nadeem, QuratulainSyed.One-factor-at-atime (OFAT) optimization of xylanase production from Trichoderma virideIR05 in solid-state fermentation. Journal of Radiation Research and Applied Sciences . (2014)317-326

K Azadi. Li, P., R. Collins, J. Tolan, J.S. Kim, K.L. Eriksson, Relationships between activities of xylanases and xylan structures, Enzyme Microb.Technol. 27 (2000) 89-94.

M.A Somogyi,.A new reagent for determination of sugar.J. Biol. Chem., 160: (1945).61 -68.

M.Bollok, ,Reczey, K., Cellulase enzyme production by various fungal strains on different carbon sources. Acta Alimentaria:29, (2005) 155-168.

O .H Lowry,..,Rosebrough , N.J ., A.L. and Randal, R.J. Protein measurement with folin phenol reagent . J. Boil. Chem., 193: (1951)265- 275.

Pandey Ajay Kumar, GnansounouEdgard b, SangeetaNegi a, Optimization of concomitant production of cellulase and xylanase from Rhizopusoryzae SN5 through EVOP-factorial design technique and application in Sorghum Stover based bioethanol production, Renewable Energy 98 . (2016)51-56

Q.K.Beg, M. Kapoor, L. Mahajan, G.S. Hoondal, Microbial xylanases and their industrial applications: a review, Appl. Microbiol. Biotechnol.56 (2001)326-338.

R Maheshwari., G. Bjardwai, M.K. Bhat, Thermophylic fungi: their physiology and enzymes, Microbiol. Mol. Biol. Rev. 64 461-488. (2000)

RosmineEmilda, NeethuChanganedasserySainjan, ReshmaSilvester, AneesaAlikkunju, SarammaAikkarakunnath Varghese, Statistical 
optimisation of xylanase production by estuarine Streptomyces sp. and its application in clarification of fruit juice, Journal of Genetic Engineering and Biotechnology. (2017).

SPSS.(2006). SPSS base 15.0User's guide. SPSS inc.,Chicago, USA.

Tallapragada P., K. Venkatesh, Isolation, identification and optimization ofxylanase enzyme produced by Aspergillusniger under submergedfermentation, J. Microbiol. Biotechnol. Res. 1 . (2011)137-147

Uday Uma Shankar Prasad, PayelChoudhury, TarunKantiBandyopadhyay,BiswanathBhunia ,Classification, mode of action and production strategy of xylanase and its application for biofuel production from water hyacinth. International Journal of Biology Macromolecules 82 (2016) 1041-1054

Yang W., F. Meng, J. Peng, P. Han, F. Fang, L, Ma, Isolation and identification of a cellulolytic bacterium from the Tibetan pig's intestine and investigation of its cellulase production, Electron. J. Biotechnol. 17(2014).262-267.

Yolanda García-Huante- Maribel Cayetano-Cruz AlejandroSantiago-Hernández- Claudia Cano-Ramírez- Rodolfo Marsch-Moreno- Jorge E. Campos · Guillermo Aguilar-Osorio · Claudia G. Benitez-Cardoza ·Sergio Trejo-Estrada María Eugenia Hidalgo-Lara The thermophilic biomass-degrading fungus ThielaviaterrestrisCo3Bag1 produces a hyperthermophilic and thermostable $\beta-1,4$-xylanase with exo- and endo-activity Extremophiles DOI 21: (2017)175-186 10.1007/s00792-0160893-Z 


\section{الملخص باللغة العربية}

\section{دراسه النشاط الانزيمى لبعض السلالات الفطريه}

\section{ثناء شلتوت ، زينب خيراللها، نور الجندى²، هاله عبد المنعم، 2، 3 محمد مجد الدين درويش، نوريش}

1 قسم النبات ــليه البنات- جامعه عين شمس - القاهر هـ مصر.

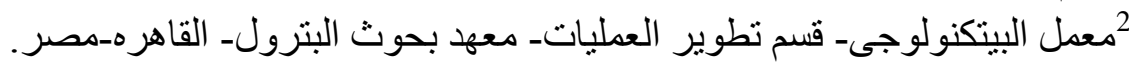

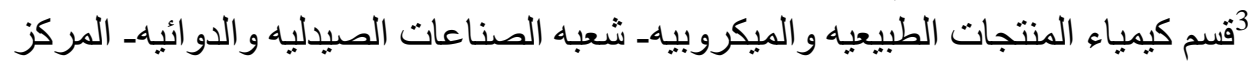

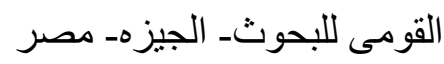

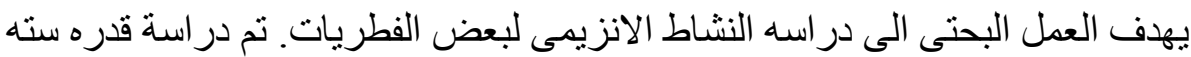

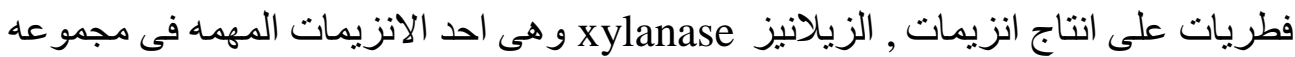

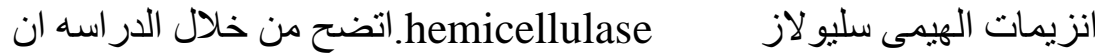
فطر Fusariummoniliforme و المعزول من الملفات القديمه وهو الاعلى انتاجيه لانزيم

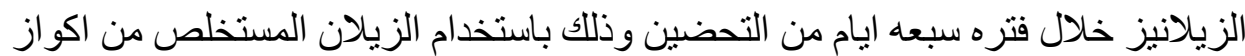

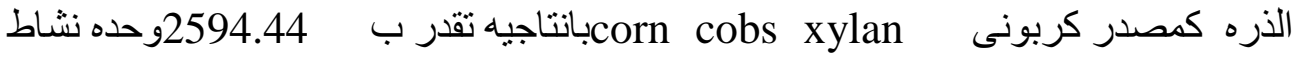
انزيميه/لتر ـاستخدم الفطر لاستتباط افضل الظروف الملائمه لتحسين انتاجيه الانزيم. اولا:

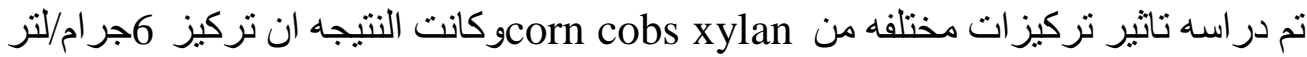

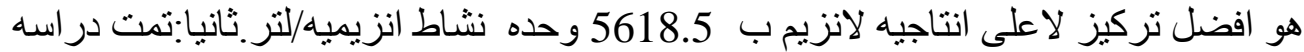

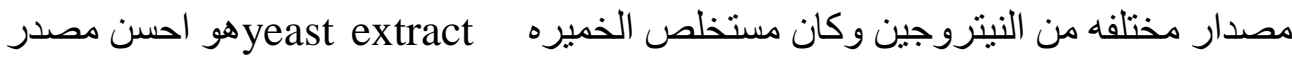
نبتروجينى استخدمه الفطر لاظهار اعلى انتاجيه لانزيم السيلانيز .ثالثا:تم در اسه تركيزات التات

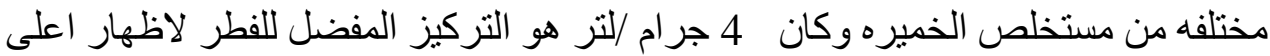

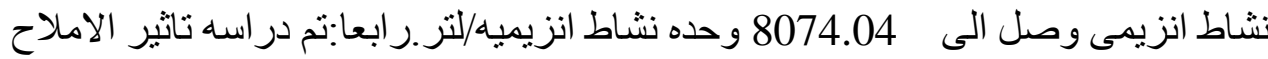

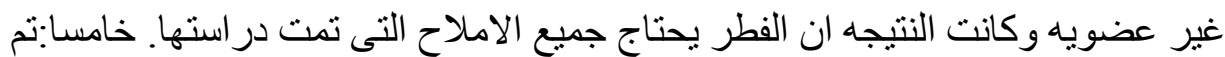

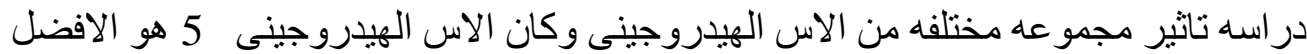
بانتاجيه وصلت الى 10950.11وحده نشاط انزيميه/لتر .سادسا: تمت در اسه احجام مختلفه

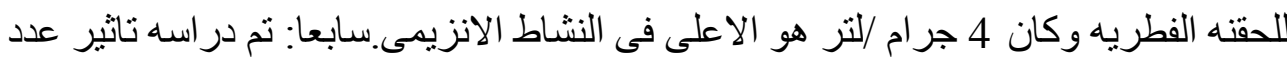
اللفات لكل دقيقه على انتاجيه الانزيم وكان 150 لفه لكل دقيقه هو الاعلى الاعلى انتاجيه.ثامنا: تمت

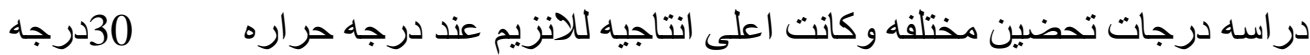

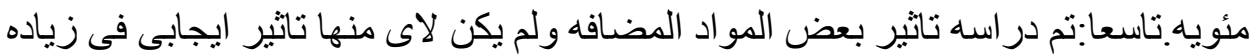

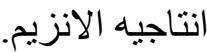

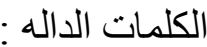

Fusariummoniliforme انزيم الزيلانيز - زيلان-فطر 